\section{Aquaculture}

February 2010, Volume 299, Issues 1-4, Pages 44-

50

http://dx.doi.org/10.1016/j.aquaculture.2009.12.009

(c) 2009 Elsevier B.V. All rights reserved.
Archimer, archive institutionnelle de l'Ifremer http://www.ifremer.fr/docelec/

\title{
Effects of age and environment on survival of summer mortality by two selected groups of the Pacific oyster Crassostrea gigas
}

\author{
Lionel Dégremont ${ }^{\mathrm{a},{ }^{*}}$, Pierre Boudry ${ }^{\mathrm{b}}$, Michel Ropert ${ }^{\mathrm{c}}$, Jean-François Samain ${ }^{\mathrm{b}}$, Edouard Bédier ${ }^{\mathrm{d}}$ and \\ Patrick Soletchnik
}

\footnotetext{
a IFREMER, Laboratoire de Génétique et Pathologie, F-17390 La Tremblade, France

${ }^{b}$ IFREMER, UMR M100 Physiologie et Ecophysiologie des Mollusques Marins, F-29280 Plouzané, France

c IFREMER, Laboratoire Environnement Ressources de Normandie, F-14520 Port en Bessin, France

d IFREMER, Laboratoire Conchylicole de Bretagne, F-56470 La Trinité, France

e IFREMER, Laboratoire Environnement Ressources des Pertuis-Charentais, F-17390 La Tremblade, France
}

\author{
*: Corresponding author : Lionel Dégremont, Tel.: +33 5467626 30; fax: +33 5467626 11, email address : \\ lionel.degremont@ifremer.fr
}

\begin{abstract}
:
This study investigated the effects of age (first or second summer of life) and environment (three study sites on French coasts) on summer mortality in Crassostrea gigas, using three generations of oysters produced during the Morest project. For each generation, two groups of oysters, selected either as 'resistant' (R) or 'susceptible' (S) to summer mortality at the age of 6 months in Rivière d'Auray (RA, South Brittany), were evaluated. In Ronce (Marennes-Oléron Bay) and RA, R oysters had low mortality during their first and second summers, while mortality was higher during the second summer in Baie des Veys (BDV, Normandy). In RA, S oysters exhibited higher mortality during their first summer than during their second, while the opposite result was found in BDV, indicating a significant environment by age interaction. Some oysters were also protected from mortality risk factors during their first year by keeping them in a nursery; they were then deployed at the two sites the following spring. Mortality in R oysters during their second year was lower than in S oysters in RA and BDV. Interestingly, mortality of the S oysters deployed in RA during their second year was much lower than the mortality observed in $S$ oysters deployed during their first year, suggesting that $S$ juveniles are more susceptible to summer mortality than $S$ adults. As a consequence, the difference in mortality between the two selected groups in RA decreased from $40-45 \%$ to $5-9 \%$ when oysters were protected from summer mortality at the juvenile stage. In BDV, the difference in mortality between the two selected groups was similar whether oysters were deployed during their first or second year. The first reproductive event in oysters, combined with genetic differences between the groups interacting with local environmental conditions can go some way to explaining summer mortality events in our study. Cumulative mortality for each generation and site was higher in the $S$ group than in the $R$ group, indicating a positive response to selection in oysters up to 18 months old. Mortality was split into three categories: low background mortality, genetic effects from the selection and unknown mortality on which no investigation has yet concentrated. Finally, culture strategy on oyster farms is discussed with respect to oyster age and environment.
\end{abstract}

Keywords: summer mortality; age; environment; genetic; Crassostrea gigas 


\section{Introduction}

Summer mortality in the Pacific oyster Crassostrea gigas has been reported in Japan (Koganezawa, 1975), on the west coast of the United States (Glude, 1975) and in France (Goulletquer et al., 1998; Samain and McCombie, 2008). Several studies have found a genetic basis for survival in $C$. gigas demonstrated by the variability of survival among stocks of different origins (Beattie et al., 1980; Hershberger et al., 1984; Soletchnik et al., 2002; Ernande et al., 2004). More recently, Dégremont et al. (2007) showed a strong genetic component and a positive response to divergent selection for survival in juvenile oysters during the summer, indicating that selective breeding could efficiently improve the trait at this life stage in C. gigas (Boudry et al., 2008; Dégremont et al., 2009). However, summer mortality also affects other age classes (Glude, 1975; Koganezawa, 1975; Maurer et al., 1986; Cheney et al., 2000; Fleury et al., 2001) and information about the genetic potential of selective breeding at early stages to improve survival at later stages is needed to explore the potential of this method and assess whether it can be used to accelerate genetic gain. In France, summer mortality is usually lower in adults than in juveniles at Rivière d'Auray (South Brittany), hereafter RA, whereas the opposite is observed in Baie des Veys (Normandy), hereafter BDV (Fleury et al., 2001; Dégremont et al., 2005; Soletchnik et al., 2007). As a consequence, it seems that an age by environment interaction occurs for summer mortality patterns in C. gigas along French coasts. In order to better understand this interaction, mortality was investigated in the field over two years, using two groups of oysters selected either as 'resistant' or 'susceptible' to the summer mortality. As the selection was made according to the survival criterion recorded at the age of 6 months on oysters tested in RA (Dégremont et al., 2009), the goal of this experiment was to determine whether the oysters selected as 'resistant' at this point maintained their high survival performances during the second year, by evaluating mortality the age of 18 months. Furthermore, it examined how survivors of a summer mortality episode during the first year performed during the second summer in a site with mortality risk factors. Similarly, batches of the two selected groups were kept in a nursery environment during their first year, where no noticeable mortality had been observed, and then deployed in the field during the second year. The purpose of this experiment was to compare the mortality of these oysters with the mortality of oysters deployed in the field during the first year. Overall, the aim of this study was to investigate the effects of age and environment on summer mortality in C. gigas using the two selected groups, comparing batches that had been protected from summer mortality risks during their first year with those which had not.

\section{Materials and methods}

\subsection{Biological materials}

Three generations of oysters, named G1, G2 and G3, were produced in 2001, 2002 and 2003, respectively, at the Ifremer hatchery in La Tremblade (Charente-Maritime, France) and grown on at the Ifremer nursery in Bouin (Vendée, France). Briefly, the G1 contained 43 fullsib families produced from a G0 wild population sampled in Charente-Maritime. From their survival performances at the age of 6 months in RA, 6 families were selected as resistant to the summer mortality phenomenon and 6 as susceptible. The G2 was then bred from these families in order to produce two selected lines, either resistant, hereafter $\mathrm{R}$, or susceptible, hereafter $\mathrm{S}$, to the summer mortality phenomenon, with each line containing several $\mathrm{R}$ or $\mathrm{S}$ batches (see below). Finally, the R and $S$ lines of the $G 3$ were bred using the $G 2$ batches as parents, without any further round of selection. For each generation, spawning was done during the winter and early spring: between February and April 2001 for the G1, in March 2002 for the G2 and in February 2003 for the G3, in order to deploy the oysters from June of 
the same year in experiment 1, or the following year in experiment 2 (Table 1). Full-sib G1 families were made by crossing one male with one female. $G 2$ batches were produced from reciprocal crosses between two G1 families and G3 from crosses between two G2 batches respectively, using around 50 males and 50 females per cross as parents. Further details on crosses, larval rearing, settlement, nursing and the selection criteria are given in Dégremont et al. (2005; 2007; 2009), and Boudry et al. (2008).

\subsection{Experiment 1: oysters deployed in the field in both their first and second year}

For each generation, the two selected groups of oysters, $\mathrm{R}$ and $\mathrm{S}$, were monitored using several $R$ and $S$ families or batches from each. In the $G 1$, the 43 full-sib families were deployed during summer 2001 (from June to July, for further details see Dégremont et al., $2005)$ in three sites along the French coasts: Ronce in the Marennes-Oléron Bay $\left(1^{\circ} 10^{\prime} \mathrm{W}\right.$, $\left.45^{\circ} 48^{\prime} \mathrm{N}\right)$, RA in Brittany $\left(2^{\circ} 57^{\prime} \mathrm{W}, 47^{\circ} 36^{\prime} \mathrm{N}\right)$, and BDV in Normandy $\left(1^{\circ} 06^{\prime} \mathrm{W}, 49^{\circ} 23^{\prime} \mathrm{N}\right)$. For each site and each family, three sealed oyster bags of 150 spat ( $7 \mathrm{~mm}$ mesh size, 100 $\mathrm{cm} \times 27 \mathrm{~cm}$ ) were randomly fixed on racks, along with a reserve bag containing 1000 spat. Mortality was recorded in all sites in October 2001 by counting the live and dead oysters in all bags except the reserve. From their survival performances recorded in RA in October 2001 , nine families showing low mortality $(6.7 \%$ in average) were selected to produce the $\mathrm{R}$ group. These families were then followed until the age of 18 months old using the oysters from the corresponding reserve bags held in each site. These oysters were redeployed at the field sites in March 2002 in 3 bags with 200 oysters each $(12 \mathrm{~mm}$ mesh size, $100 \mathrm{~cm} \times$ $52 \mathrm{~cm}$ ) per family except in Ronce where it was only 162 oysters $( \pm 22 \mathrm{SD})$ per bag due to massive natural settlement of wild spat in summer 2001 . Only oysters without too many wild spat stuck to them could be used, while clusters of oysters were discarded as it was not possible to distinguish the wild oysters from the hatchery-produced ones. Mortality was again recorded for all bags in each site in October 2002. The main objective of this experiment was to determine whether $\mathrm{R}$ oysters selected from their survival performances at the age of 6 months maintained their high survival during the second year.

Similarly, eight G1 families showing high mortality (52.0\% in average) in RA in October 2001 were selected to produce the S group, but they were only monitored until the age of 18 months old at this one site (Table 1). Due to the high mortality observed for the $S$ families during the first summer, only one or two bags per family were redeployed from the reserve bag in March 2002, and the number of oysters ranged from 104 to 246 per replicate (average $189 \pm 37$ SD). Dégremont (2003) found that density (from 75 to 150) did not influence summer mortality and Dégremont et al. (2005) showed that the replicate effect was not significant, allowing us to assume these two effects had little or no impact on mortality observed during the second summer of exposure to mortality risks in the field. The main objective was to determine the difference in mortality between R and S oysters at 6 and 18 months age in RA.

For the G2, five batches of the $G 2 R$ line and five batches of $G 2 S$ line were used to make up the $R$ and $S$ groups, respectively. The two resulting $G 2$ groups were tested in RA from July 2002 to October 2003. The first year, each batch was represented by 3 bags of 150 oysters, and mortality was recorded in October 2002. During the second year, all batches were equally mixed within each group, as batches perform similarly in separate and communal stocking evaluations (Dégremont, 2003). Each group was then redeployed into three bags of 100 oysters in March 2003 and mortality recorded in October 2003 (Table 1). In the same way as for the G1, the main objective was to determine the difference of mortality between the two selected groups at 6 and 18 months as well as to use the 6-month-old oysters as an indicator of summer mortality in RA to aid the assessment of 18-month-old oysters from the G1, which were tested at the same time.

Finally for the G3, R and S groups were each made up of five batches from the corresponding selected line. As in the G2 evaluation during the second year, all batches were mixed within group ( $\mathrm{R}$ or $\mathrm{S}$ ) with an equal contribution of each batch. Each group was 
deployed in RA and BDV in June 2003, and was represented by three bags of 150 oysters in each site. In BDV, groups were redeployed into three bags of 100 oysters per group in March 2004. However, the RA site had to be abandoned in 2004, due to massive mortality during the first year. Mortality was recorded in October 2003 and October 2004 (Table 1). The main objective was to determine the summer mortality of the two selected groups of the G3 at 6 and 18 months old in BDV and to use the 6-month-old oysters of the G3 as an indicator of summer mortality in RA for assessing 18-month-old oysters of the G2, which were tested in this site at the same time.

\subsection{Experiment 2: oysters protected from summer mortality during their first year, then deployed in the field during their second year.}

During their first year, oysters were held at the Ifremer nursery facility in Bouin where no noticeable mortality was observed, then deployed during the fall either in a pond located in Marennes-Oleron Bay (G1 and G2) or in the west coast of Normandy (G3). For each generation, two selected groups were created by mixing equally five R- or S-selected families or batches. Groups of the G1 and G2 were deployed in RA in March 2002 and March 2003 respectively, while G3 groups were deployed in RA and BDV in March 2004. Each group was represented by three bags of 200 oysters for the G1, whereas three bags of 100 oysters were used for the G2 and G3. Mortality was recorded in October, i.e. seven months after their deployment in the field (Table 1). The main objective of experiment 2 was to determine the mortality of the two selected groups at 18 months old in BDV and particularly in RA where summer mortality usually affects juveniles more.

\subsection{Statistical analyses}

Differences in mortality among groups (R and S), sites (RA, BDV and Ronce), ages (6 and 18 months old), experiments ( 1 or 2 ) and the interactions between these factors were analyzed for each generation using a logistic regression for binomial data with the GENMOD procedure (McCullagh and Nelder, 1989; SAS Institute Inc., 1995). Several models were used as different groups, and generations were deployed and tested either in one, two or three sites and during one or two years. For example, the following model was used to test the $\mathrm{R}$ group of the $\mathrm{G} 1$ in the three sites for 6 - and 18-month-old oysters:

Logit $\left(Y_{i j}\right)=\mu+$ age $_{i}+$ site $_{j}+$ age $_{i} \times$ site $_{j}$

where $Y_{i j}$ is the probability of mortality for the ith age (6 and 18 months old) at the jth site (RA, BDV, Ronce), and $\mu$, site, age and site $x$ age are the intercept, site effect, age effect and interaction effect, respectively.

Comparisons among groups, sites, ages and experiments were conducted using the least squares mean statements of the GENMOD procedure (Littell et al., 2002). All analyses were conducted using SAS version 9. A value of $P<0.05$ was considered significant.

\section{Results}

\subsection{Experiment 1: oysters deployed in the field in both their first and second year}

Mortality in the R group of the G1 was 3.3, 4.0 and $6.7 \%$ at 6 months and $23.9,4.7$ and 8.0 $\%$ at 18 months in BDV, Ronce and RA, respectively (Table 2), and a significant site by age interaction was found. Within site, the $\mathrm{R}$ group showed low and similar mortality for both ages in Ronce and RA, while a significant difference in mortality between ages was found in BDV with higher mortality at 18 months (Table 2). Similarly, significant differences of 
mortality among sites were found at 6 and 18 months, with higher mortality in BDV, especially at 18 months (Table 2 ).

At 6 months, mortality in RA was 7, 6 and $38 \%$ for the R group and 52, 48 and $83 \%$ for the $\mathrm{S}$ group for the G1, G2 and G3, respectively (Fig. 1). Conversely, low and similar mortalities (6-8 \%) were observed for the two groups at 18 months for the $G 1$ and the G2. Age by group interaction was significant for the G1 and G2. Within group, for the G1 and G2, the S group had significant higher mortality at 6 months than at 18 months. Within age, the $S$ group had significantly higher mortality than the R group at 6 months in $G 1, G 2$ and $G 3$, while no significant difference of mortality between the two selected groups was found at 18 months in G1 and G2.

In BDV, R and S groups of the G3 showed low mortality at 6 months with 2 and $6 \%$, respectively. Higher mortality was found at 18 months in both groups with $20 \%$ and $42 \%$ for $\mathrm{R}$ and $\mathrm{S}$ groups, respectively (Fig. 2). Interaction between age and group was found non significant, while significant differences of mortality were found between groups and between ages.

\subsection{Experiment 2: oysters protected from summer mortality in their first year and deployed in the field in their second year}

At the age of 18 months in RA, the R group showed significantly lower mortality (4-6\%) than the S group (14\%) for the G1 in 2002 and G2 in 2003 (Fig. 3).

For the G3, mortality at 18 months was 22 and $27 \%$ for the $\mathrm{R}$ and the $\mathrm{S}$ groups respectively in RA (Fig. 3), while it was 12 and $33 \%$ for the R and the S groups respectively in BDV (Fig. 2). Site by group interaction was found significant. Within site, mortality was only significantly different between the two groups in BDV. Within group, no significant difference in mortality was found between the two sites.

\subsection{Comparison of cumulative mortality between experiments 1 and 2 at $\mathbf{1 8}$ months}

The cumulative mortality recorded within experiment, site and group is shown in Table 3 . For the $\mathrm{G} 1$ in RA and the G3 in BDV, interaction between groups and experiment was not significant. Significant differences in cumulative mortality were found between the two experiments and between the two groups though, with the highest mortality in experiment 1 (oysters deployed at 6 months) and the highest mortality in the S group (Table 3). For the $\mathrm{G} 2$ and G3 tested in RA, the interaction between groups and experiments were significant, but mortality was always higher in experiment 1 for both groups.

\section{Discussion}

\subsection{Experiment 1: oysters deployed in the field in both their first and second year}

Animals deployed in RA: In RA, where both $\mathrm{S}$ and $\mathrm{R}$ groups were tested, at 6 months $\mathrm{S}$ oysters from the $\mathrm{G} 1$ showed higher mortality than R oysters, while at 18 months $\mathrm{S}$ survivors had high survival and performed as well as R oysters (Fig. 1). These findings are supported by those observed for the $\mathrm{G} 2$. Therefore, $\mathrm{S}$ oysters are more fragile at the juvenile stage than at the adult stage and the genetic difference between the two selected groups for mortality in RA was revealed during the first year, but not during the second. Lower mortality was expected in the second year due to the way the lines had been selected and the high heritability of the selected trait (Dégremont et al., 2007). A first hypothesis to explain the low mortality in the two selected groups at 18 months in G1 and G2 could be a favorable environment that prevented the summer mortality phenomenon at this time. However, this 
hypothesis was rejected as the 6-month-old S groups of the G2 and G3 were present on the field site at the same time and suffered high summer mortality losses (Fig. 1). A second hypothesis to explain the low mortality in the two selected groups and the lack of difference in mortality between them at 18 months could combine (1), for the R group, the superior genetic-based characteristic to survive up to 18 months, due to the selection criterion and (2), for the $S$ group, the high mortality recorded for the $S$ oysters at 6 months old leading to the elimination of sensitive animals from this group. This would imply that all or nearly all oysters with genetic-based sensitivity to summer mortality died during the first summer period, leaving stronger individuals in the group that was tested the next year.

Interestingly, differences in mortality between the $\mathrm{R}$ and $\mathrm{S}$ groups for the three successive generations were relatively constant, ranging from 42 to $45 \%$ difference in the first year in RA, even though the mortality of the R and S groups was much higher in the G3 (38 and 83 $\%$ respectively) than in the G1 (7 and $52 \%)$ and G2 (6 and $48 \%)$ (Fig. 1). The higher mortality observed in the G3 may be a consequence of the heatwave observed in France in 2003 (Black and Sutton, 2007). Similar findings were also observed in all selected batches and controls produced in the G3, tested along the French Atlantic coasts in other sites (Boudry et al., 2008). Surprisingly, environmental conditions in 2003 only induced higher mortality at 6 months in the G3, while lower mortality was found at 18 months in the G2, even when oysters were protected from summer mortality during their first year (Fig. 1 and 3); a result supporting the idea that juveniles are much more susceptible to summer mortality than adults in RA.

Higher mortality in younger oysters compared with older ones has previously been reported by Maurer et al. (1986) and Brown and Hartwick (1988). These authors concluded that young oysters were more susceptible to environmental variation than older ones, due to their higher metabolic demand (Maurer and Borel, 1986) - an interpretation that could also explain our results. Furthermore, in the Morest project, $\mathrm{R}$ and $\mathrm{S}$ oysters were found to have different reproductive patterns, with the $\mathrm{R}$ oysters spawning earlier in the summer than the $\mathrm{S}$ oysters (Samain and McCombie, 2008). Thus, $\mathrm{S}$ oysters should invest more energy in reproduction than $\mathrm{R}$ oysters, the latter having then more energy available to cope with biotic or abiotic stress and therefore being more likely to survive such pressures. As the oysters were produced during the winter, environmental conditions in RA allowed the oysters to experience their first gametogenesis from the age of three months and their first spawning at the age of 6 months. As all susceptible $S$ oysters died the first year, both selected groups would be expected to have a similar reproduction pattern during the second year, but further investigation is needed to explore this hypothesis.

From the three successive generations tested in RA in experiment 1 , mortality could be divided into three different categories for the juvenile $C$. gigas at 6 months. The first category is identified as low background mortality, around 6-7\%, which was observed in the R group of $\mathrm{G} 1$ and $\mathrm{G} 2$. The second type of mortality was shown to be due to the genetic selection, with $42-45 \%$ of mortality due to the difference in resistance between the two selected groups in all generations (Fig 1.). These two categories of mortality were relatively constant in the years from 2001 to 2003. The last category of mortality, which is considered as mortality of unknown origin, varied from 0 to $30 \%$ among years, affected both groups at the same intensity, and was likely induced by environmental conditions such as those encountered in 2003. At 18 months, only the 'background' mortality was observed in RA, which was again low (7-8 \%) (Fig. 1).

Animals deployed in BDV: For the G1, higher mortality was found in older oysters than younger ones in the $\mathrm{R}$ group (Table 2). However, no $\mathrm{S}$ group was present in the field at the same time, so no comparison between the R and $S$ groups was possible. For the G3, the two selected groups were tested at 6 and 18 months. While mortality remained low for both groups at 6 months, corresponding to background mortality, higher mortality was observed for both groups at 18 months (Fig. 2), confirming that adult oysters had higher summer mortality than juvenile ones in BDV (Fig. 2) (Fleury et al., 2001; Royer et al., 2007). 
However, mortality of the $\mathrm{R}$ group was lower than mortality of the $\mathrm{S}$ group at 18 months, indicating that the selection based on mortality in the first year had a positive response for resistance to mortality in the second year in BDV. However, the third category of mortality, which we refer to as unknown mortality, was also observed at 18 months, reaching around $20 \%$ for the two selected groups of the G3 in 2004 and for the R group of the G1 in 2002 . It is not possible to affirm if this unknown mortality had the same origin as that observed in RA, which was attributed to the heat wave. As for RA, reproduction may explain our results. Indeed, seawater temperature is lower in BDV than in RA (Dégremont et al., 2005; Soletchnik et al., 2007), which delayed first reproduction to the second year in BDV and could thus explain why there was a greater difference in mortality between the selected groups at 18 months than at 6 months. Finally, RA and BDV mortality patterns at 6 and 18 months revealed a clear site by age interaction for the summer mortality phenomenon in $C$. gigas in France.

\subsection{Comparison of mortality between both experiments at $\mathbf{1 8}$ months}

Animals deployed in BDV: In BDV, difference in mortality between the two selected groups due to selection was 21-22 \% in both experiments (with and without the first year in a protected environment; Fig. 2). So S oysters showed susceptibility to summer mortality at the same level, regardless of the age at which they were deployed in the field. However, the annual mortality was lower in experiment 2 (12 and $33 \%)$ than in experiment 1 (20 and 42 $\%)$. This reduction was linked to the unknown form of mortality, that is to say mortality that had not been targeted by the selective breeding. Thus, environmental conditions that oysters encountered during the first year might have affected mortality recorded during the second year.

Animals deployed in RA: Differences in mortality between the $\mathrm{R}$ and $\mathrm{S}$ groups were low in all generations, ranging from 5 to $10 \%$ (Fig. 3). Thus, the mortality resulting from selection applied in the Morest breeding program could still be observed during the second year in experiment 2, but to a much lesser extent than during the first year in experiment 1 (Fig. 1). Thus, adult $\mathrm{S}$ oysters were less susceptible to summer mortality in RA than S juveniles were, even though the former did not experience any mortality during their first year.

Unknown mortality: The third category of mortality, presently of unknown origin, was observed for the first time in the G3 at 18 months in RA (Fig. 3), indicating that juvenile and adult $C$. gigas could be both affected by it in this site. It is also interesting to note that it was again observed in 2008 for both selected groups (data not shown), which suggests that it appears in particular environmental conditions (i.e. heat wave in 2003 , unusual mild winter in 2008). This matches perfectly with the spawning period of the oysters tested in 2003 and 2008. Indeed, the G3 were produced in February 2003, then experienced the exceptionally warm summer that led to the unknown mortality in RA in 2003, (experiment 1) but also in 2004 in RA and BDV throughout oysters that had been protected from summer mortality risks during their first year (experiment 2), suggesting that environmental conditions of a particular year could have had an effect on oyster mortality recorded the following year. The selected groups tested in 2008 (data not shown), were produced in June 2007, meaning that they experienced the mild winter temperature in 2008 that preceded the mortality during summer 2008. To summarize, most of the mortality in our experiments could be explained, but an unknown form of mortality was also revealed and further investigations are required in order to assess its importance in different environments and on oysters of different ages. 


\subsection{Advice to oyster farmers in order to limit summer mortality in oysters:}

Two important points were underlined by this study. First, G1 and G2 R oysters presented low mortalities (4 to $8 \%$ per year) at 6 and 18 months in RA and Ronce, indicating that oysters maintained their high survival into their second year (Table 2) - an age at which oysters are harvested in some growing areas in France. Second, mortality was significantly reduced by the use of $R$ oysters compared to $S$ oysters at all ages and all environments (Table 3). Consequently, growers could use selected oysters resistant to the summer mortality phenomenon in order to increase cumulative survival and thus company output. Our experiment also provides some advice on cultural practices aimed to minimize summer mortality in C. gigas. In RA, the critical period when the highest genetic difference in summer mortality was observed was at the juvenile stage, while in BDV this was at the adult stage. Oyster farmers should, therefore, grow their oysters in BDV during the first year and transfer them to RA before the following spring. French cultural practices currently use large-scale transfer of oysters between rearing areas (Goulletquer and Le Moine, 2002). Unfortunately, this can also spread large numbers of pathogens throughout the ensemble of French production areas, as was suggested to explain the massive mortality outbreak recorded simultaneously among all production areas in France in 2008. Consequently, transfers should be avoided during the summer mortality risk period, mainly between April and September.

Most oyster farmers want to know if it is worth keeping the oysters that survive a mortality outbreak. Indeed, it would not make economic sense to keep these oyster batches if they continued to die the following year. Through experiment 1 in RA, we found that the surviving $\mathrm{S}$ oysters of a massive mortality outbreak had higher survival and performed as well as $\mathrm{R}$ oysters. Farmers could, therefore, grow the surviving oysters of a mortality outbreak, which had occurred when these were at the juvenile stage, without great risk of another mortality outbreak when these oysters are older. However, it is further recommended that oyster farmers use R oysters, which should limit the mortality level and so increase profits.

Cumulative mortality at 18 months for the oysters in experiment 2 was lower than for the oysters in experiment 1, in RA and BDV (Table 3). Even though the difference in mortality between these experiments was 'only' 10 and $12 \%$ for the R and S groups, respectively, in BDV this is a reduction of 45 and $27 \%$ of the mortality for the R and S groups respectively when oysters were protected from mortality risks the first year, which is likely to be economically significant. Similarly, reduction of mortality in oysters of experiment 2, compared with oysters of experiment 1, was even higher in RA and reached an average of $62 \%$. As a consequence, protecting spat from mortality risks during their first year allows good survival performances to be maintained during the second year in a site where heavy mortality usually occurs in juvenile oysters. Thus, the cumulative mortality at 18 months could be significantly reduced by maintaining juvenile oysters in a good environment in the first year. In our experiment, the good environment during the first summer was a nursery facility. Its characteristics are described in Bacher and Baud (1992) and could be summarized as high flow water, ad libitum feeding and no emersion. Interestingly, this finding is supported by the massive mortality outbreaks that affected juvenile $C$. gigas in France during 2008 and 2009. Indeed, no mortality outbreaks were observed in either year in a private commercial nursery located in Bouin that rears several hundred million juveniles annually, although heavy mortality was reported at sea. However, it is not possible for oyster farmers to have their own nurseries, so we suggest either growing spat in deeper water or in BDV or buying spat after the critical mortality risk period, which is to say after the summer period, knowing that between October and March, mortality risks are limited. For BDV, oysters must be transferred before the following spring to another environment where the mortality risk is known to be low at the adult stage. 


\section{Acknowledgements}

The authors wish to thank the hatchery and nursery teams (IFREMER-LGP, La Tremblade and IFREMER-LCPL, Bouin, France) for technical assistance during the larval and nursing phases and the IFREMER coastal laboratory teams for the fieldwork and data acquisition (LCB, La Trinité sur Mer, LERPC, Ronce les Bains and LERN, Port en Bessin, France). This work was a part of the national project Morest on summer mortality in $C$. gigas.

\section{References}

Bacher, C., Baud, J.P., 1992. Intensive rearing of juvenile oysters Crassostrea gigas in an upwelling system: optimization of biological production. Aquat. Living Resour. 5, 89-98.

Beattie, J.H., Chew, K.K., Hershberger, W.K., 1980. Differential survival of selected strains of Pacific oysters (Crassostrea gigas) during summer mortality. Proc. Natl. Shellfish. Assoc. 70, 184-189.

Black, E., Sutton, R., 2007. The influence of oceanic conditions on the hot European summer of 2003. Clim. dyn. 28, 53-66.

Boudry, P., Dégremont, L., Haffray, P., 2008. The genetic basis of summer mortality in Pacific oyster spat and potential for improving survival by selective breeding in France. In: Summer mortality of Pacific oyster Crassostrea gigas. The Morest Project. Quae Editions, Versailles, pp.153-196.

Brown, J.R., Hartwick, E.B, 1988. Influences of temperature, salinity and available food upon suspended culture of the Pacific oyster, Crassostrea gigas. 2. Condition index and survival. Aquaculture 70, 253-267.

Cheney, D.P., MacDonald, B.F., Elston, R.A., 2000. Summer mortality of pacific oysters, Crassostrea gigas (Thunberg): Initial findings on multiple environmental stressors in Puget Sound, Washington, 1998. J. Shellfish Res. 19, 353-359.

Dégremont, L., 2003. Etude des bases génétiques des mortalités estivales et relation avec la croissance chez les juvéniles de Crassostrea gigas. Thèse de Doctorat de l'Université de Caen, France. (333p).

Dégremont, L., Bédier, E., Soletchnik, P., Ropert, M., Huvet, A., Moal, J., Samain, J.F., Boudry, P., 2005. Relative importance of family, site, and field placement timing on survival, growth and yield of hatchery-produced Pacific oyster spat (Crassostrea gigas). Aquaculture 249, 213-229.

Dégremont, L., Ernande, B., Bédier, E., Boudry, P., 2007. Summer mortality of hatcheryproduced Pacific oyster spat (Crassostrea gigas). I. Estimation of genetic parameters for survival and growth. Aquaculture 262, 41-53.

Dégremont, L., Bédier, E., Boudry, P., 2009. Summer mortality of hatchery-produced Pacific oyster spat (Crassostrea gigas). II. Response to selection for survival and its influence on growth and yield. Aquaculture doi:10.1016/j.aquaculture.2009.11.017.

Ernande, B., Boudry, P., Clobert, J., Haure, J., 2004. Plasticity in resource allocation based life history traits in the Pacific oyster, Crassostrea gigas. I Spatial variation in food abundance. J. Evol. Biol. 17: 342-356.

Fleury, P.G., Goyard, E., Mazurie, J., Claude, S., Bouget, J.F., Langlade, A., Le Coguic, Y., 2001. The assessing of Pacific oyster (Crassostrea gigas) rearing performances by the IFREMER/REMORA network: method and first results (1993-98) in Brittany (France). Hydrobiologia 465, 195-208.

Glude, J.B., 1975. A summary report of Pacific coast oyster mortality investigations 19651972. 1-28. In: Proceedings of the Third U.S.-Japan Meeting on Aquaculture, Tokyo, Japan. October 15-16, 1974, pp. 1-28. 
Goulletquer, P., Le Moine, O., 2002. Shellfish farming and Coastal Zone Management (CZM) development in the Marennes-Oléron Bay and Charentais Sounds (Charente Maritime, France): A review of recent developments. Aquacult. Int. 10, 507-525.

Hershberger, W.K., Perdue, J.A., Beattie, J.H., 1984. Genetic selection and systematic breeding in Pacific oyster culture. Aquaculture 39, 237-245.

Koganezawa, A., 1975. Present status of studies on the mass mortality of cultured oysters in Japan and its prevention. In: Proceedings of the Third U.S.-Japan Meeting on Aquaculture. Tokyo, Japan, October 15-16, 1974, pp. 29-34.

Littell, R.C., Stroup, W.W., Freund, R.J., 2002. SAS ${ }^{\circledR}$ for Linear Models, Fourth Edition. Cary, NC: SAS Institute Inc. $466 \mathrm{p}$.

Maurer, D., Borel, M., 1986. Croissance, engraissement et cycle sexuel de Crassostrea gigas dans le bassin d'Arcachon : comparaison des huîtres âgées de 1 et 2 ans. Haliotis 15, 125-134.

Maurer, D., Comps M., His, E., 1986. Caractéristiques des mortalités estivales de l'huître Crassostrea gigas dans le bassin d'Arcachon. Haliotis 15, 309-317.

McCullagh, P., Nelder, J.A., 1989. Generalized linear models. Monographs on statistics and applied probability $\mathrm{n}^{\circ} 37$. Chapman and Hall, London, $511 \mathrm{p}$.

Royer, J., Ropert, M., Costil, K., 2007. Spatio-temporal changes in mortality, growth and condition of the Pacific oyster, Crassostrea gigas, in Normandy (France). J. Shellfish Res. 26, 973-984.

Samain, J.F., McCombie, H., 2008. Summer mortality of Pacific oyster Crassostrea gigas. The Morest Project. Quae Editions, Versailles, 379p.

SAS Institute Inc., 1995. Basis statistics using SAS/STAT®, software course notes. Cary, NC: SAS Institute Inc., 720 p.

Soletchnik, P., Huvet, A., Le Moine, O., Razet D., Geairon, P., Faury N., Goulletquer, P., Boudry, P., 2002. A comparative field study of growth, survival and reproduction of Crassostrea gigas, C-angulata and their hybrids. Aquat. Living Resour. 15, 243-250.

Soletchnik, P., Ropert, M., Mazurie, J., Fleury, P. G., Le Coz, F., 2007. Relationships between oyster mortality patterns and environmental data from monitoring databases along the coasts of France. Aquaculture 271, 384-400.

\section{Tables}


Table 1. Summary of experiments 1 and 2: generation, site, group, months of deployment in the field and mortality sampling.

\begin{tabular}{|c|c|c|c|c|c|c|}
\hline Experiment $^{a}$ & Generation $^{b}$ & Site $^{c}$ & Group $^{d}$ & $\begin{array}{l}\text { Months of deployment in the } \\
\text { field }\end{array}$ & Months of mortality recorded & Age at sampling \\
\hline 1 & G1 & RA & $R-S$ & June to August 2001 & October 2001 and 2002 & 6 and 18 months old \\
\hline 1 & G1 & BDV & $\mathrm{R}$ & June to August 2001 & October 2001 and 2002 & 6 and 18 months old \\
\hline 1 & G1 & Ronce & $\mathrm{R}$ & June to August 2001 & October 2001 and 2002 & 6 and 18 months old \\
\hline 1 & G2 & RA & R -S & July 2002 & October 2002 and 2003 & 6 and 18 months old \\
\hline 1 & G3 & RA & $R-S$ & June 2003 & October 2003 & 6 months old \\
\hline 1 & G3 & BDV & $R-S$ & June 2003 & October 2003 and 2004 & 6 and 18 months old \\
\hline 2 & G1 & RA & $R-S$ & March 2002 & October 2002 & 18 months old \\
\hline 2 & $\mathrm{G} 2$ & RA & $R-S$ & March 2003 & October 2003 & 18 months old \\
\hline 2 & G3 & RA & $R-S$ & March 2004 & October 2004 & 18 months old \\
\hline 2 & G3 & BDV & $R-S$ & March 2004 & October 2004 & 18 months old \\
\hline
\end{tabular}

a: In experiment 1, oysters were deployed in the field during their first year; in experiment 2, oysters were protected from mortality their first year and then deployed in the field during their second year.

b: G1, G2 and G3 were produced between February and April in 2001, 2002 and 2003, respectively.

c: RA = Rivière d'Auray and BDV = Baie des Veys

d: $\mathrm{R}$ and $\mathrm{S}$ are selected oyster groups, 'resistant' and 'susceptible' to summer mortality, respectively. 
Table 2. Mortality (\%) of the $\mathrm{R}$ group in the three sites for the first generation at 6 and 18 months old (Experiment 1 ).

\begin{tabular}{llll} 
Age & BDV & Ronce & RA \\
\hline 6 months & $3.3 \pm 2.1^{\mathrm{a}}$ & $4.0 \pm 3.6^{\mathrm{a}}$ & $6.7 \pm 3.9^{\mathrm{b}}$ \\
18 months & $23.9 \pm 10.3^{\mathrm{c}}$ & $4.7 \pm 1.9^{\mathrm{a}}$ & $8.0 \pm 3.4^{\mathrm{b}}$ \\
\hline
\end{tabular}

a: Means with different superscripts differ significantly $(P<0.05)$ among sites within age group. RA $=$ Rivière d'Auray and BDV $=$ Baie des Veys

Table 3. Cumulative mortality (\%) at 18 months old of the two selected groups in the two experiments.

\begin{tabular}{llllll}
\hline Generation & Site & \multicolumn{2}{c}{ Experiment 1} & \multicolumn{2}{c}{ Experiment 2 } \\
& & R & S & R & S \\
\hline G1 & RA & 14 & 55 & 5 & 14 \\
G2 & RA & 11 & 52 & 6 & 14 \\
G3 & RA & $\geq 38$ & $\geq 83$ & 22 & 27 \\
G3 & BDV & 22 & 45 & 12 & 33 \\
\hline RA & Rivière d'Auray and & BDV & B Baie des Veys & &
\end{tabular}

$\mathrm{R}$ and $\mathrm{S}$ are selected oyster groups, 'resistant' and 'susceptible' to summer mortality, respectively.

\section{Figures}



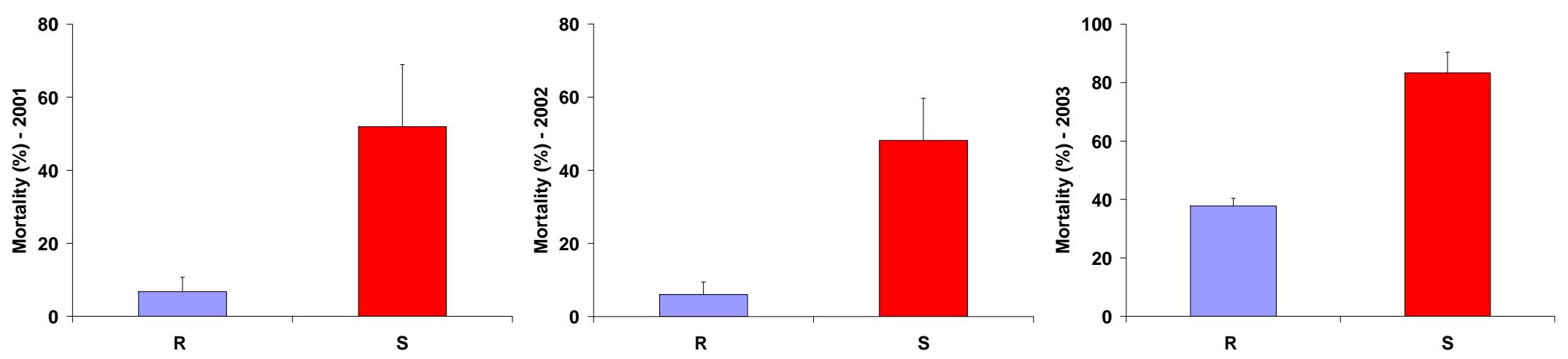

\section{6 months}
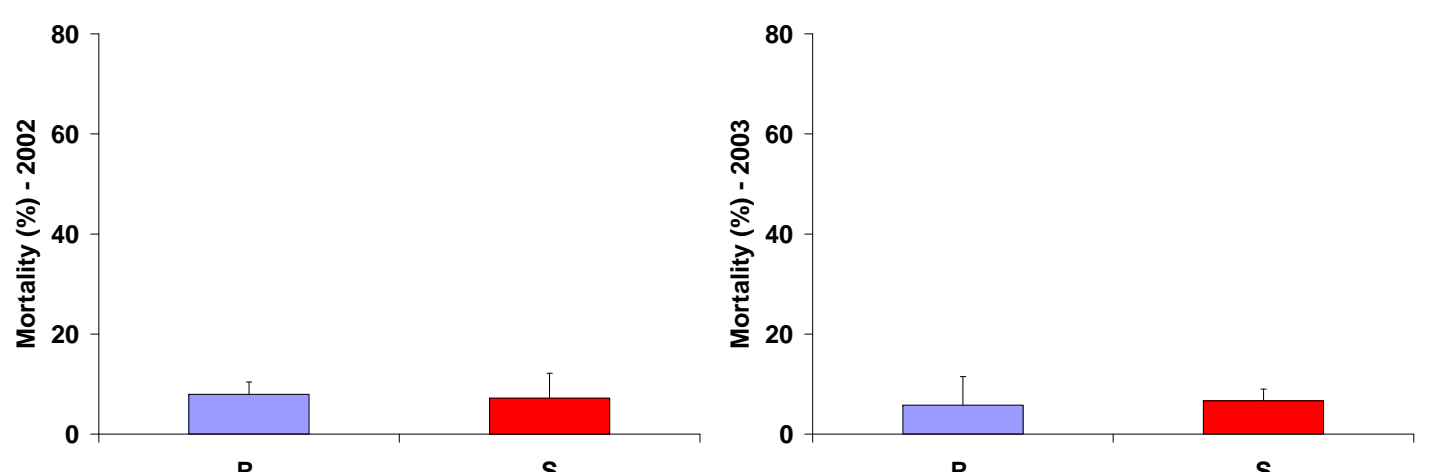

18 months

R

S

R

s

Fig. 1: Annual mortality (mean and standard deviation ) of the $\mathrm{R}$ and $\mathrm{S}$ groups for the three generations tested in experiment 1 in Rivière d'Auray (RA). R and S are selected oyster groups, 'resistant' and 'susceptible' to summer mortality, respectively. 
Experiment $1^{\mathrm{a}}$

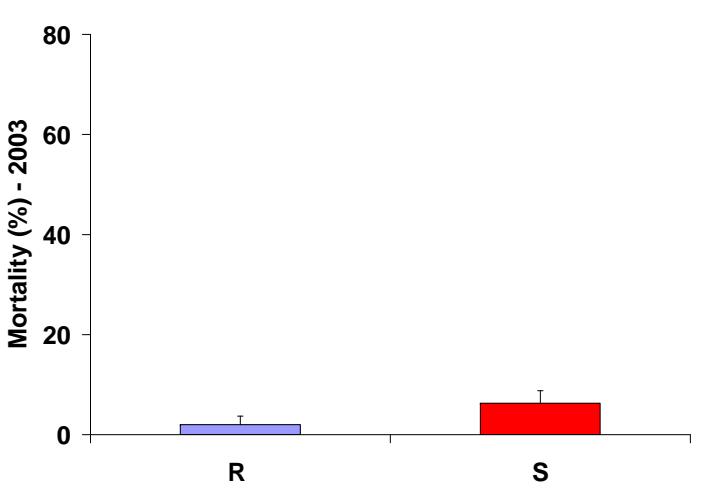

6 months

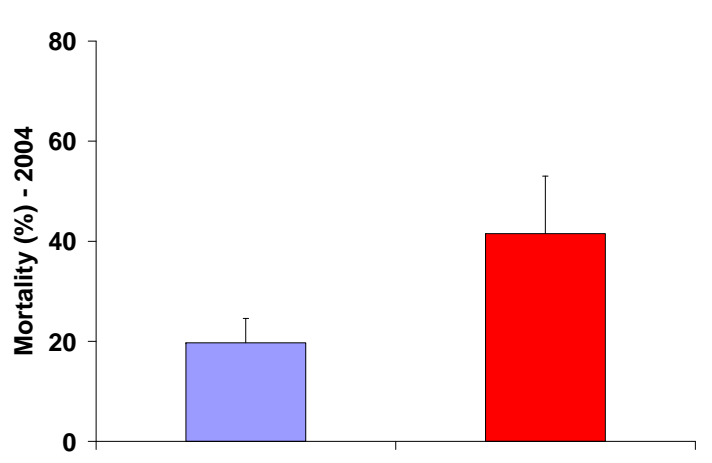

18 months
Experiment $2^{a}$
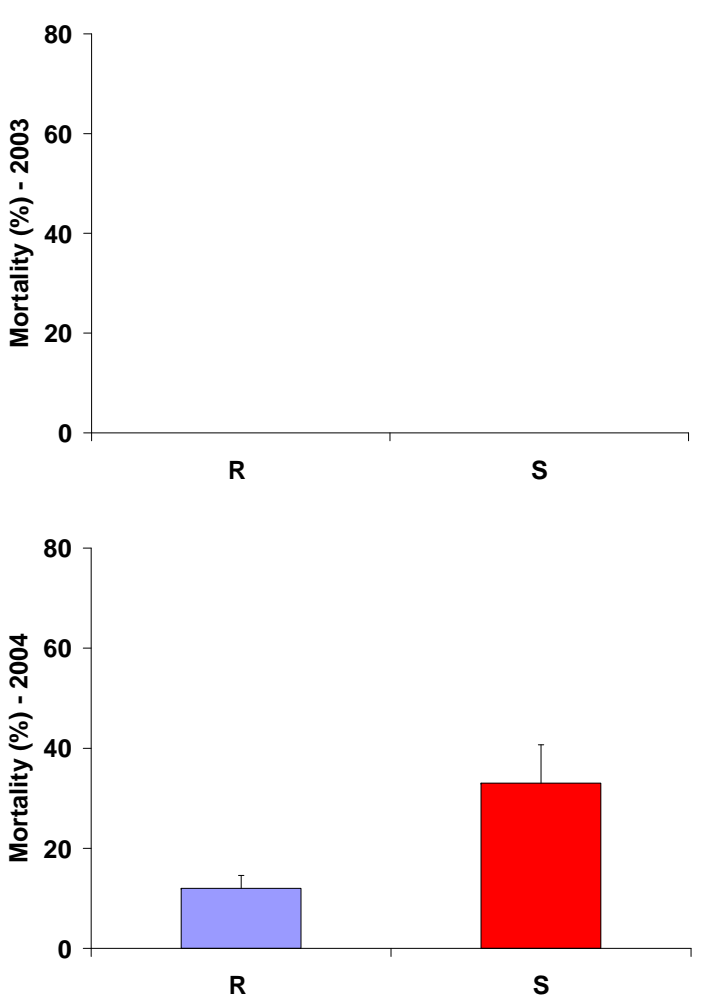

Fig. 2: Annual mortality (mean and standard deviation) for the $R$ and $S$ groups in experiments 1 and 2 of the G3 in Baie des Veys (BDV).

${ }^{a}$ In experiment 1 , oysters were deployed in the field during their first year; in experiment 2, oysters were protected from mortality their first year and then deployed in the field during their second year. Thus, mortality for both groups at 6 months in Experiment 2 was zero. R and $S$ are selected oyster groups, 'resistant' and 'susceptible' to summer mortality, respectively. 
G1

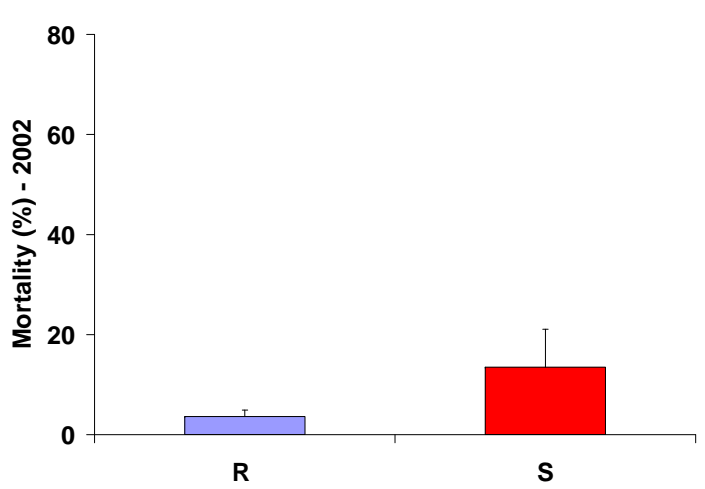

G2

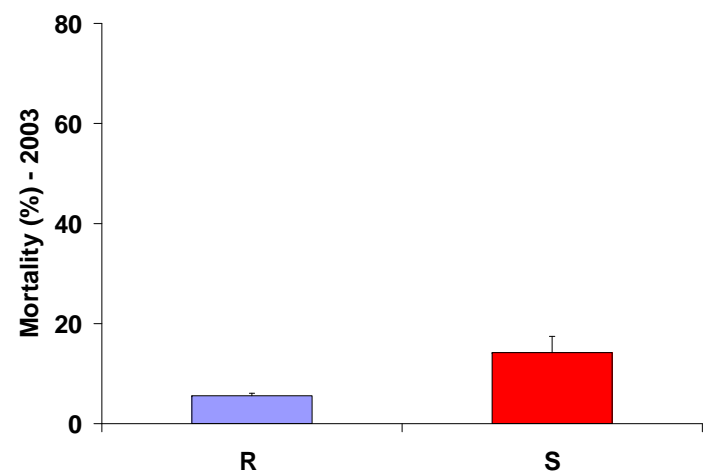

G3

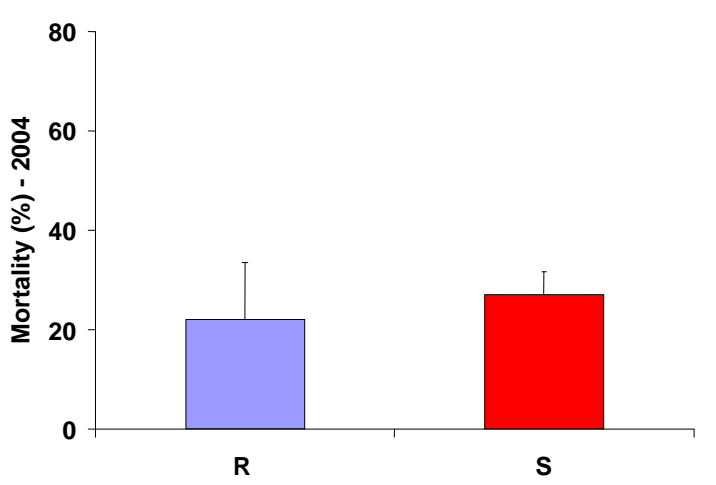

Fig. 3: Annual mortality (mean and standard deviation) in the second year (18 months) of the $\mathrm{R}$ and $\mathrm{S}$ groups protected from mortality risks during their first year (experiment 2), for the three generations reared in Rivière d'Auray (RA). 